Instructions for authors, subscriptions and further details:

\title{
"A Real Man Cries": A Scoping of Filipino Masculinities Construction in Tweets
}

John Erwin Bañez ${ }^{1}$

1) University of the Philippines, the Philippines

Date of publication: October $21^{\text {st }}, 2021$

Edition period: June 2021 - October 2021

To cite this article: Bañez, J. E. (2021). "A Real Man Cries": A Scoping of Filipino Masculinities Construction in Tweets. Masculinities and Social Change, 10 (3) 216-241. https://doi.org/10.17583/MCS.2020.8634

To link this article: https://doi.org/10.17583/MCS.2020.8634

PLEASE SCROLL DOWN FOR ARTICLE

The terms and conditions of use are related to the Open Journal System and to Creative Commons Attribution License (CC-BY). 


\title{
"A Real Man cries": A Scoping of Filipino Masculinities Construction in Tweets
}

John Erwin Bañez

University of the Philippines

\begin{abstract}
Online content can be a rich source of information on current constructions of masculinities and much can be explored on the digital's role in masculinities construction (Light, 2013). This study compares and contrasts our current literature on masculinities with empirical qualitative data - that is, Filipino tweets. To do this, I analyzed tweets containing the phrase "ang tunay na lalake" (the real man) and the hashtag "\#angtunaynalalake". Using qualitative content analysis, the following themes were generated: 1) Romance and Masculinities which highlights heteronormativity of romantic context and the concept of "more deserving real man" - a construct produced through networked masculinity and within the context of fandom and bigotry; 2) Masculine Capital - highlights how rites of passage, specifically circumcision, can be overshadowed by masculine capital to the point that failing to meet the required masculine capital would render one as 'de-circumcised'; and lastly, 3) Online Resistance to Hegemonic Masculinity - shows the use of jokes, sarcasm, and confrontation in questioning hegemonic masculinity. The results show both concern and hope for gender advocacy.
\end{abstract}

Keywords: hegemonic masculinity, masculine capital, online identity construction, Philippines 


\title{
"Un hombre de Verdad Llora": Construcción de Masculinidades Filipinas en Tweets
}

\author{
John Erwin Bañez \\ University of the Philippines
}

\section{Resumen}

El contenido en línea puede ser una rica fuente de información sobre las construcciones actuales de masculinidades y se puede explorar mucho sobre el papel de lo digital en la construcción de masculinidades (Light, 2013). Este estudio compara y contrasta nuestra literatura actual sobre masculinidades con datos cualitativos empíricos, es decir, tweets filipinos. Para ello, analicé tweets que contenían la frase "ang tunay na lalake" (el hombre real) y el hashtag "\#angtunaynalalake". Utilizando un análisis de contenido cualitativo, se generaron los siguientes temas: 1) Romance y masculinidades, que destaca la heteronormatividad del contexto romántico y el concepto de "hombre real más merecedor", una construcción producida a través de la "masculinidad en red" y dentro del contexto del fanatismo y la intolerancia; 2) Capital masculino: destaca cómo los ritos de iniciación, específicamente la circuncisión, pueden verse eclipsados por el capital masculino hasta el punto de que no cumplir con el capital masculino requerido lo convertiría en "descircunciso"; y por último, 3) Resistencia en línea a la masculinidad hegemónica: muestra el uso de bromas, sarcasmo y confrontación para cuestionar la masculinidad hegemónica. Los resultados muestran tanto preocupación como esperanza por la promoción de género.

Palabras clave: masculinidad hegemónica, capital masculino, construcción de identidad en línea, Filipinas 


\section{Bañez-A Real Man Cries}

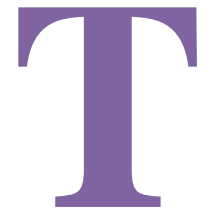

his study is motivated by a tweet on March 19, 2019, that sparked an online discussion on what a real man is or should be. The tweet was:

May dalawang baklang nasa loob ng trike. They saw us wearing dress and skirt. And dahil nasa loob sila sa likod kami ng trike sasakay. Pero sabi nila 'mga ate, rito na kayo sa loob. Nakapalda kayo e kami nakapekpek short lang naman'. (There were two gays inside the tricycle. They saw us wearing a dress and a skirt. Since they were inside, we were ready to ride behind the driver. But they said, 'Sisters, you can ride inside. You are wearing skirts while we are just wearing short shorts.')

A tricycle is a motorcycle with a sidecar, a Filipino vehicle used in public transportation. Riding inside the sidecar is considered safer, and if you are wearing a skirt, less likely to involuntarily expose the passenger's legs. The tweet was meant to express gratitude to two flamboyant gay men for giving their seats to Angel and her friends. While the tweet was about giving thanks, the comments highlight an observation that men no longer practice this act of giving up a seat in public transportation, which is expected from real men. Instead, gay men do what is expected from real men. It generated 3,905 retweets and 14,347 likes. This was also shared on Facebook and garnered 49,000 reactions and 68,951 shares. Comments and reactions were mixed and showed the tensions and contradictions of Filipino society's definition of what a 'real man' is. Some agreed with 'Angel' and expressed gender equality sentiments. Some disagreed. One comment insisted that this should not be a big deal since being a woman is not a disability and men should be allowed to sit (i.e. not give way to women) because this is also their right. Some used the 'not all men are like that' argument. Others claimed that women would pretend to want equality, but what they actually want is to have authority over men. The contradictions in real man discourse as found in Filipino tweets, apart from the story of Angel above, will be the focus of this study.

The aim is to surface Filipino masculinities construction on Twitter. In doing so, stimulate discussion to the question "what are Filipino masculinities as constructed online"? This question does not intend to require a single answer, rather, it encourages discussion of Filipino masculinities as they relate 
to the literature of masculinities. This is particularly important because the literature on Asian online discourse on masculinities remains scarce. The study does not intend to come up with a comprehensive discourse of masculinities, rather, this is a glimpse of 'what is out there' in the 'Twitter world'. While limited, this is considered important since online discourse is increasingly becoming part of our lives as the anonymity and reach it offers can incentivize sharing opinions that would rather be censored in 'real world' interactions.

Since I intended to compare and contrast themes found in the tweets with literature on masculinities, much of the literature was discussed alongside the data (i.e., harvested tweets). First, I briefly presented important points on masculinities studies, namely, plurality and hierarchy (hence, the existence of hegemony). This was followed by literature on Filipino masculinities. Online social media identity construction followed to provide a common ground on how we can appreciate online content as part of our reality. I then zoomed into online masculinity construction and its link to social change. The method used in the study was presented next, followed by constructed themes juxtaposed with salient points of masculinities literature. I concluded by highlighting facets of masculinities found in this study, that is, the concept of "more deserving real man" constructed through "networked masculinity", that masculine capital can outperform rites of passage to manhood (specifically, circumcision), and lastly, a Filipino brand of resistance to hegemonic masculinity - one that is seasoned with jokes, sarcasm, and confrontation.

\section{A Survey of Masculinities Studies}

For at least two decades, the concept of hegemonic masculinity (Connell \& Messerschmidt, 2005) has greatly influenced masculinity studies. What follows are some features of hegemonic masculinity as developed by Connell and Messerschmidt (2005). The idea of hegemonic masculinity is founded on plurality and hierarchy of masculinities. Implicit in this idea is the existence of nonhegemonic masculinities and that the hierarchy of masculinities is brought by the process of hegemony and not by force alone. Hegemonic masculinity is not necessarily the most common masculinity seen in the lives of boys and men, yet it is a persistent standard. Also, while hegemonic masculinity can have persistent features, it can vary depending on location, 
culture, history, and specific context such as work, sports, and age. Hence, a man may need to adapt when moving from one context to another. The original formulation of hegemonic masculinity also emphasizes the reality that the dominant can be resisted and changed, thereby creating new hegemonic patterns of masculinities. The plural form, masculinities, highlights the varied "forms of manhood we construct" and recognizes that "masculinity means different things to different groups of men at different times" (Kimmel, 2001, p. 22)

These definitions are intertwined with politics as some definitions are privileged while some are marginalized. Understanding masculinities is important as it can be key to unraveling the operation of "power in practice" (Hanlon, 2012, as cited in Elliot, 2016, p. 246), reduce, if not eradicate, the "high cost of masculinity" (Elliot, 2016, p. 247), and improve men's engagement in gender equality. This engagement is believed to have a "humanizing effect on men" (Elliot, 2016, p.247).

\section{Literature on Filipino Masculinities}

Some literature on Filipino masculinities focused on identifying factors that define Filipino masculinities, and attendant expectations from these definitions. Aguiling-Dalisay, Heugten, and Domingo's (1995) pioneering work on Filipino masculinities looked at the concepts of manhood, real man, and fulfilled man from the perspectives of three cultural groups in the Philippines. They found, across cultures, there were similarities and differences in how 'real man' was defined. The commonality was more pronounced in terms of the biological aspects and family responsibilities of 'real man' while differences were driven more by cultural and psycho-social dimensions. For example, Maranaw respondents gave characteristics of the Prophet Mohammed as the benchmark of masculinity. Meanwhile, university education was seen to influence respondents from Iloilo when they asserted that masculinity is cultural and not innate. Rubio and Green (2011) identified dimensions of Filipino Masculinity using the Filipino Adherence to Masculinity Expectations (FAME) scale. They identified Assertiveness and Dominance, Family Orientedness, Sense of Community, Responsibility, Integrity, Intelligence and Academic Achievement, and Respectful Deference to Women and Elderly as significant dimensions of Filipino masculinity. 
Some focused on negotiations - the framing and reframing of Filipino masculinities in the context of migration and shifting economic roles and coping mechanisms to express masculinities. Margold (1995) described how Filipino migrants in the middle east experienced intimidation, humiliation, sexual assault, and other forms of tensions as subordinates in the workplace, and how these tensions somehow 'partially disassemble' (p.276) one's masculinity and how migrants maneuvered to recover or negotiate his manhood. Nadal and Corpus (2012) examined the experiences of LGBT Filipino Americans and found empirical evidence of how religion, culture, race, and family expectations become significant factors as one negotiated with multiple identities.

Lastly, to emphasize the importance of masculinity studies, Angeles (2001) discussed the potential and prospect of the inclusion of men and masculinities in Gender and Development Studies. The literature on Filipino masculinities as reflected in the unique setup of the 'online world' remains scarce. The rich amount of online data can give us updated sentiment on Filipino masculinities, allowing us to sense whether there are shifting views, reinforcement of the status quo, or both. This can point to the further enrichment of the study of masculinities.

\section{Social Media and Identity Construction}

Given that this study used online posts, it was important to frame how we can make sense of such data. Should we take online posts seriously? Some have multiple social network accounts so, who is posting online? How do the realities we form online relate to our 'physical world'? We find ourselves concerned with questions like these as we realized the effect of our online world (Hongladarom, 2011). We now speak of 'self' (or 'offline self') and 'online self'. The former refers to the physical self, located in the 'physical world' and the latter refers to our online presence in the 'online world', including our profiles (boyd, 2008 as cited in Aresta, Pedro, Santos, \& Moreira, 2015), content (Zhao, Grasmuck, \& Martin, 2008, as cited in Aresta et. al., 2015), and type and level of participation (Fraser, 2009 as cited in Aresta et. al., 2015). 
However, in our complex social reality, these apparently separate worlds do overlap from time to time, and perhaps more and more over time. While it is true that what our 'physical self' performs is open to multiple interpretations because of multiple audiences, the actual self is confined by physical constraints. Thus, its audience is more likely to come from less varied social contexts. On the contrary, the performance of the online self is amplified and stored by technology such that audiences now include those from social contexts that are very different from that of the offline self (Aresta, Pedro, Santos, \& Moreira, 2015). At the same time, online platforms now provide more options and circumstances to construct, express, and explore our multiple selves (Livingstone, 2008, as cited in Siibak, 2010; Aresta, et. al. 2015). Social media has changed the production and communication of content from one-to-many to many-to-many (Humphreys and Vered, 2014) so messages are now exposed to interpretation from varied contexts and audiences. Indeed, the ground-breaking work of Turkle (1995, as cited in Siibak, 2010) on multiple selves is manifested as we explore different selfpresentations online.

It should also be noted that our interaction with and utility of the online platforms changes how one reconstructs and even rediscovers her offline self (Butler, 1990, as cited in Hongladarom, 2011; Buckingham, 2008, as cited in Aresta, et. al., 2015; Terras, Ramsay \& Boyle, 2015). Humphreys and Vered (2014) noted that in the online gaming context, where avatars were used in the performance of gender, both constraints and opportunities offered by avatar options allow a gamer to explore an "alternate representation" (p. 7).

As audiences of the online context, we ought to have a frame in understanding online messages, one that can give a handle on how the online and the offline relates with each other. One perspective is online messages should be seen in the light of "impressions management" where we either suppress or accentuate parts of self (Goffman, 1959 as cited in Aresta et. al.). More so, Clark (2005, as cited in Siibak, 2010) found that online impression management's goal was to be "acceptable or simply okay in the context of peers" (p. 217). Petkova (2005, as cited in Siibak, 2010) argued that we switch easily between real and chosen ("ought" (p.405)) online identity. Hence, what we broadcast online could indicate varying social constructions of what is acceptable for different peers in different contexts as well. 
Another view is offline and online selves do not differ. They are both selective in what to reveal and to whom (Zhao, et. al. 2008) and constructed based on information sent from the physical world to the online environments (boyd, 2008). Indeed, utilizing online platforms more and more makes differentiating online self and offline self harder. But when we realize that the need to and the way we distinguish is also a construct (Hongladarom, 2011), why should we differentiate at all? Another way is to treat the offline and online as contexts which Terras et. al. (2015) described as both transactional and exhibiting spatio-temporal changes.

The need to connect the online and offline self is due to our need to see real, felt, tangible social changes offline. We wonder, with all the noise for social change and supposed connectedness generated online, where are we heading? Can the online context be an indicator of real-world social change or lack of it? Research below point to both disturbing realities and some hope.

\section{Examples of Online Masculinity Construction and Online Social Change}

The online context provides a place where masculinities are constructed and reconstructed. This online construction process is dynamic as it is driven by offline self, the aspired image, the features of the chosen online platform, and the audience. We also see that these constructions are double-edged - on one hand, an online context is a place where one can curate either manosphere messages (Ging, personal correspondence, September 23, 2019), on the other hand, push for social change such as resistance to hegemonic masculinity can also be done

Siibak (2010) studied profile photos of young Estonians to see if there were changes in traditional masculinity constructions. She found that different versions of masculinity were portrayed, and varied audiences were imagined. The profile photos showed sexual, romantic, and longing young males. The photos also complemented the textual description of the self.

Light (2013) coined the term networked masculinities - 'those masculinities (co)produced and reproduced with digitally networked publics' (p.253) and that the (co)production and reproduction of masculinities 'potentially involve the input of other people' making people subject to 'being inscribed with particular readings' (p.257). He argued that the features of social network sites such as anonymity, reproducibility, replicability, 
scalability, persistence, and searchability of online content made possible 'hyper-public constructions of masculinity' (p. 258).

Ging (2017) drew our attention to the 'manosphere' - a loose online network where antifeminism, Red Pill philosophy, and men's liberation discourses abound. In the manosphere, we see how extreme misogyny, messages of genetic determinism, women's subjugation, and toxic masculinity in the offline world are amplified and reinforced by anonymity and relative like-mindedness. On a positive note, digital activism in the form of blogs, vlogs, and hashtags also abound (PettyJohn, Muzzey, Maas \& McCauley, 2019). For example, \#HowIWillChange was started not only hear the opinions of other men about rape culture but also to prod men to commit to necessary behavioral changes. PettyJohn et. al. (2019) argued that the online context created by \#HowIWillChange provided space for men to join a conversation they would initially feel unsafe to engage in for fear of being perceived as weak. However, in the research, a spectrum of responses was seen, ranging from 'active dismantling of rape culture' to hostile 'resistance to change' (p.1).

\section{The Study}

This study investigated 'tweets' about masculinity as indicated by '\#angtunaynalalake' and the phrase 'ang tunay na lalake' ('real man'). These tweets were framed in this study as signals of perceptions of Twitter users about acceptable masculinity in a specific part of South East Asia. The tweets were framed as a product of impression management which revealed what was considered important by the Twitter user. This study attempted to see if the tweets pointed to disturbing realities (e.g. extreme misogyny), or to hope (e.g. social change).

$R$ Studio, an open-source software, was used to harvest tweets via $\mathrm{R}$ packages 'twitteR' and 'rtweet'. In this method, Twitter selects tweets that are publicly available for the last seven days (Kearney, n.d.; twitter.developer.com, n.d.). There were two data collection points, April 16 and 29, 2019 and a total of 210 tweets with hashtags and 1,090 without hashtags were collected. It should also be noted that more search results do not have a hashtag (\#), rather, the phrase "tunay na lalake" is used to extract tweets. There were also Filipino tweets that express one's definition of 'real 
man' by using other phrases (e.g. "yan ang lalake" (that's a real man)) without the hashtag '\#angtunaynalalake'. Some of these tweets were manually extracted (i.e. not via R Studio) to provide a better context to harvested tweets via R Studio. Tweets including 'supot' (uncircumcised) were also extracted using R Studio since the term is the opposite of circumcised - a key masculine attribute in the Philippines. While the tweets are already pseudonymized, usernames were also deleted as an added data privacy protection.

Using qualitative content analysis, original tweets were coded and summarized to identify prominent themes. Schreier (2014) defined qualitative content analysis as 'data reducing, systematic, and flexible', allowing the researcher to 'focus on selected aspects of meaning' (i.e. those which relate to the research question) where a passage is 'taken to a higher level of abstraction' (p. 2) (emphasis mine). The following Steps in Qualitative Content Analysis (p.6) were used: 1) Deciding on a research question; 2) Selecting Material; 3) Building a coding frame; 4) Segmentation; 5) Trial Coding; 6) Evaluating and modifying the coding frame; 7) Main analysis; and 8) Presenting and interpreting the findings. This method is usually used to analyze Twitter data (PettyJohn, et. al. 2018). Whether the tweets were articulated by men or women would not be the interest of the study. It is also impossible to ascertain this information in the online context.

The themes were created based on similarities or convergence of content. The themes were juxtaposed with masculinities literature to highlight the applicability of the literature and possible divergence from the literature which may point to other areas of studies in masculinities.

\section{Results}

The following themes which encapsulate masculinities in the tweets were derived: 1) Romance and Masculinities; 2) Masculine Capital, and; 3) Resistance to Hegemonic Masculinity. It should be noted that the themes overlap, thus, some tweets may be seen to also belong to another theme. Nonetheless, the themes offer useful frames to better understand Filipino masculinities. It would not be feasible to present all harvested tweets. Instead, tweets that encapsulate the theme better were presented. 


\section{Romance and Masculinities}

Romance is a space where one can prove his masculinity as the tweet below suggests.

Kung maaari sana ay bigyan mo ako ng panahon upang patunayan sa iyo na iba ang tunay na lalake sa lalake lamang (If it is possible, give me time to prove to you that there is a difference between a man and a 'real man').

There is general acceptance that men and women vary in how they do 'emotion work'. Duncombe and Marsden (1993) argued that the gender asymmetry of 'emotion work' is highlighted in the disclosure of intimacy in the context of heterosexual relationships, where men are typically less emotionally expressive verbally than their female partners. Disclosure is seen by men to lead to emotional vulnerability, and 'messy uncertainty' (McQueen, 2017, p. 209) that counters control of one's self, a core masculinity feature. The same study showed that, in the context of therapeutic discourse, there was an acceptance that emotional disclosure was healthy. Duncombe and Marsden (1993) reported that men were exposed to the same range of emotions as women but either don't know how to disclose them or value emotions as too private to share - even to their partners. Interestingly, Talbot and Quayle (2010) showed that some women, while wanting their partners to disclose more, require that disclosure should not be done at the expense of core features of masculinity (e.g. provider and protector). Consistent in these researches was the ability of men to navigate their context, adjusting their disclosure behavior and by doing so, they tend to maintain their hegemonic status (Allen, 2004; Ging, 2017). Allen (2007) in a study of romance experienced by young heterosexual men, noted that gendered power relations, as defined by hegemonic masculinity, constructed romance. Interestingly, the tweets harvested used words loaded with emotions such as love, vulnerability, courage, and respect. However, they may still reinforce the 'chivalrousdamsel in distress' idea of romantic heterosexual partnership. Under this theme, we have four sub-themes: Monogamous and Heteronormal, Courage in Courtship, Respect, and 'More Deserving Real Man'. 
Monogamous and heteronormal. Heterosexual romance was seen as a chance to prove one's masculinity. The tweets below resonate with what is common to many extracted tweets. It suggests that a 'real man' should be romantically involved with $\boldsymbol{a}$ woman, emphasizing not just heteronormativity but monogamous relationships as well.

Ang tunay na lalake, hindi umiibig sa kapwa lalake. (A real man does not fall for another man).

Ang tunay na lalake, maraming 'babae'. Maraming 'babaeng' dapat iwasan para sa isang 'babaeng' dapat iniingatan (A real man has a lot of women, a lot of women he avoids for that one woman he should be cherishing).

Notice the use of a factual sounding 'hindi umiibig' (do not fall for). This has a 'matter-of-factly', 'conscious decision' kind of tone, a construction that comes from a heteronormal culture. The second tweet implies two things. First, that a 'real man' attracts or is attracted to a lot of women, and second, a 'real man' would decide to avoid these women because he is faithful to his partner whom he should be taking care of. Again, this implies a heteronormal relationship, but emphasis is given to the requirement of a monogamous relationship for one to qualify as a 'real man'. Notice here, if a man has multiple (female) partners, he is not a real man but this does not mean he is branded as gay. So 'real man' discourse in this context seems to have other points of comparison and not just real man vis-a-vis gay man. More in-depth research can be done on this. On an interesting note, these tweets are also a pushback against womanizing men - a feature of toxic masculinity.

Courage in Courtship. Some tweets seem to come from the context of courtship demanding courage. As proof of masculinity, a man should be courageous to face high standards, go the extra mile in making sure 'the woman' arrives home safely, and is not afraid of a woman's father. 
Girls, Raise your standards!!! Dahil ang tunay na lalake di takot sa standards!! (Girls...!!! A real man is not afraid of standards!!).

Tunay na lalake walang takot takot maihatid lang ang babae na ligtas sa kanyang balay (emoticon) saludo ako sayo tol (A real man has no fear in making sure (his) woman safely arrives home. I salute you).

Ang tunay na lalake hindi takot sa tatay ng babae. (A real man does not fear the woman's father).

This last tweet may imply tension or rivalry between the father and suitor since from a patriarchal culture, which is still dominant in the Philippines, daughters are initially viewed as possessions of their fathers.

Courage also has other actuations. Courage is to court a woman face to face and not via 'sms'. Courage is to 'change for a woman' versus to 'change women partners' (or go through a series of women). Courage is the ability to be emotional and say 'I love you'. These expressions of courage are fused with expressions of heterosexual romance.

Ang tunay na lalake mag sabi siya sayo na mahal ka niya (A real man will tell you he loves you).

Ang tunay na lalake Hindi sa text nangliligaw Dapat sa personal (A real man doesn't court via text message, he should do it personally).

Ang tunay na lalake magbabago ng kusa para sa pinakamamahal niya (A real man would change out of his own accord for the person he loves the most).

Ang tunay na lalake nagbabago para sa babae, hindi pabago bago ng babae! (A real man 'changes for a woman' not 'changes women').

Respect. Another commonality in the tweets has to do with calls to respect women. To one Twitter user, this attribute is non-negotiable. 'Real men' can show 'respect' for women in different ways. One is by adhering to the 
unwritten code of never 'kiss and tell':

di pwedeng tawaging 'tunay na lalake' ang hindi maalam rumespeto sa mga babae!! (You can't call a person a real man if he does not know how to respect women!!).

Pre naka score na ko sa kanya... Sabi ko sayo easy to get yun' Kung may nangyari man, manahimik nalang sana. Preserve her name \& dignity. $U$ touched her soul not her body. Good in bed pero bad in attitude. ANG TUNAY NA LALAKE MAY RESPETO. ('Dude, I had sex with her'... 'I told you she is 'easy to get'. If something happened, keep it to yourself...A REAL MAN HAS RESPECT).

... dahil ang tunay na lalake di nananakit ng babae kapag nagmahal ka kahit wala na kayo, ang sikreto ay sikreto (a real man would not hurt a woman and if you are no longer together, your secrets should remain a secret)

In these tweets, respect is also made synonymous with non-violent behavior, keeping intimacy a secret, and being faithful to one's partner. This is more related to 'respectful deference to women' by Rubio and Green (2011) than to Bourgois' (1995) 'Respect' which connotes conquering women and drinking subcultures. On the other hand, the tweets may be expressions of how women are viewed as properties of men, in need of taking care of. This view infantilizes women to reinforce man's protector and savior persona.

The More Deserving 'Real Man'. So far, we have seen tweets that come from the heteronormal directive. To take this to another level, some tweets indicate that a 'real man' is someone who deserves the ideal woman. Almost always, the 'more deserving real man' is someone who embodies hegemonic masculinity. A trending Twitter topic pits two Filipino actors (Alden and Arjo) who were perceived by their fans as competing for a woman (Maine - a famous actress in the Philippines). Fans from both sides would use 'real man' as the criterion as to who deserves Maine. 
Oh here's another one. Ang bobo mo. Ang kaibahan nila...si Arjo tunay na lalake. Si Alden, nanla lalake (Oh here's another one. You are stupid. The difference between them. . . Arjo is a real man. Alden, likes men).

In the tweet below, Arjo is 'accused' of gaining publicity at Maine's expense, a behavior that put's his 'real man' status suspect:

... Kung tunay kang lalake at mahal mo ang babae, hindi mo gagamitin sa lahat ng interview mo ang kanyang pangalan. Alam mong nababash siya, ulit ulit mong binabanggit kahit di sya kasama sa movies mo (...If you are a real man and you love the woman, you would not use her name in all your interviews. You already know she is being bashed, but you repeatedly mention her even if she is not part of your movies).

Another tweet comes with Arjo's photo which portrays Arjo as a flamboyant and effeminate man with inserted text 'Bakclash'. The text 'Bakclash' is a play of words combining Bakla (gay) and backlash. There is a dedicated hashtag for this discourse, \#AldubNationHoldingOn, used by fans who think Alden is the one who deserves Maine, i.e. not Arjo. These are viral tweets and they reinforce the notion that i.) subordinate masculinity (e.g. gay) is used as a label to discredit someone, and ii.) whoever has hegemonic masculinity (i.e. 'real man') is subjective. Arjo and Alden are both 'real men' depending on whom you talk to. In this case, the 'real man' is whoever deserves the 'ideal woman'.

We observed here what Light (2013) called 'networked masculinities' which was defined as 'those masculinities (co)produced and reproduced with digitally networked publics' (p. 253) and that the (co)production and reproduction of masculinities 'potentially involve the input of other people' making people subject to 'being inscribed with particular readings' (p.257). I expound that networked masculinities is also a process where a group of people (crowd) perform masculinity construction online for another person or group of people (target). The masculine construct is curated and inscribed to a target by the crowd via editing of online content (such as videos, pictures, and interviews) such that the preferred masculinity of the crowd is given 
credence. The preferred masculinity of the crowd is usually preconceived and loaded with bias. The purpose of this process is to either discredit or revere a target. Networked masculinity is fueled by affinity or disgust with a target. In the case above, there are two targets, Alden and Arjo and they have their crowds. Each of their crowds is revering the target they have an affinity with and discrediting the other they despise.

\section{Masculine Capital}

Vasquez del Aguila (2014) defined masculine capital as a 'a form of cultural capital that provides men with the necessary "masculine" skills and cultural competence to achieve legitimacy and social recognition as respected men". This "includes acquisition of certain masculine manners, body postures, sexual expertise, ability in sports (such as soccer), control, and display of emotions' (p.67). This means masculine capital consists of iterated performances. The cultural appropriateness or inappropriateness of these iterative performances may increase or decrease masculine capital. Under this theme, we have two subthemes discussed below.

Composure under pressure. Masculine capital means certain actions must be done correctly should one wish to establish 'real man' status. Deviations from these expectations merit suspicions of being less than a 'real man'. One expectation shown in tweets is composure: "Paano kabahan ang Isang Tan? Yan yung tunay na lalake! (How does a Tan get nervous? That is a real man!)"

The tweet above is accompanied by a video clip ${ }^{1}$ from PBB teens (a Philippine version of The Big Brother) showing Tan, a Filipino teen celebrity, nervously waiting for 'Ashley', a girl he seems to adore. In the short clip, Tan is shown talking to himself, shaking off his nerves by moving his body, and brushing his hair with his hands - all in a 'manly and acceptable way'. The comments following the tweet seemed to show that he was perceived to be composing himself and that he is doing a good job at it. 
Composure outside the context of romance is also considered. The tweet below gives an opinion on how a 'real man' should handle even a disturbing situation such as sexual harassment:

.....Pano madami nambash sa post nya. Hindi naman kasi ganyan ang reaction ng tunay na lalake pag nahipoan (A lot of people bashed him. A real man shouldn't react that way when groped).

To which one replied: "Korik kung tunay na lalake yan hnd yan mag iskandalo (Correct, if he is a real man he won't make a scandal)".

Circumcised but still uncircumcised. Circumcision is part of the checklist to becoming a Filipino man (Aguiling-Dalisay, et. al., 1995). In some places in the Philippines, it is still a public performance, in the sense that people will easily know if you have just been circumcised. Boys usually have to wear skirts as the wound from circumcision heals. Parents and relatives also discuss if and when a boy will be circumcised.

tulian na bukas madadagdagan nanaman ang mga tunay na lalake (Tomorrow is circumcision day. More will be added to real men).

inaasar si ibong na di pa siya tunay na lalake kasi di pa siya tuli (They are mocking Ibong, that he is not yet a 'real man' because he has not been circumcised).

However, by performing 'unmanly' characters and gestures, a circumcised man will be socially reverted as an 'inferior man'. This is understood better by looking at the use of the local term for uncircumcised or 'Supot', also a derogatory term, used to insult men who are perceived to be weak, effeminate, or who simply do not 'make the cut' (figuratively) of a 'real man'.

_ 1v1 matalo supot (One on one challenge the loser is 'uncircumcised').

Tapos kanina chinat ako ng tropa ko sa Quezon kung pwede daw ba akong ligawan Sabi ko tuloy sakanya. Supot ka pa boi whahahhaha 
(Earlier, my friend sent a chat asking if he can court me. I said to him, boy, you are still uncircumcised whahahaha).

Often, the term 'supot' is used in jest to police one's masculinity - akin to 'fag' in Pascoe (2007) where it was shown, the use of 'fag' is sometimes used in jest but also to police someone's gender identity. The first tweet was about challenging someone with the loser being labeled as 'supot' (uncircumcised). The second was about the use of 'supot' in rejecting someone's (romantic) proposal. Note, no physical inspection of the penis is required to label someone as 'supot'. Rather, the lack of observed masculine capital is enough for someone to be labeled as 'supot'. These tweets imply the words circumcised and uncircumcised can have two meanings - physical and social un/circumcision, and that social uncircumcision or the lack of masculine capital may overshadow physical circumcision. That is, it would not matter if you are physically circumcised. If you do not muster your masculine capital (e.g. winning a challenge), or if the girl you like does not like you, you are labelled '(socially) uncircumcised': "Ang dami na namang supot kahit tuli na" (Many are 'uncircumcised' even if they are circumcised); "tuli ka na supot ka pa rin" (You are circumcised but you are still uncircumcised).

This reinforces that the 'real man' image is not static and has to be sustained, that rite of passage may not be enough in some contexts. This may add pressure to a man especially since masculine capital changes throughout the life cycle (adolescence, elderly) and in various contexts (e.g. socioeconomic), and over time (Vasquez del Aguila, 2014).

\section{Online Resistance to Hegemonic Masculinity}

Hegemonic masculinity morphs continuously (Connell \& Messerschmidt, 2005), sometimes faster in one context and slower in another. Often, this evolution is fueled by resistance.

Resistance through jokes and sarcasm. From the extracted tweets, we see jokes and touches of sarcasm such as tweets about having a big belly and fear of cockroaches. This is very Filipino. Ancheta (2011) in her study of Filipino humour said: 
humor is, in fact, a Filipino national weapon - - one that is utilized not only to reflect social foibles and cultural beliefs that allow Filipinos to find belonging in using humor as a response to crippling national horrors, but one that is used too to train an apparently disparaging look at themselves as victims of embarrassing, painful historical or political circumstances (p. 56).

Hence, while these tweets are jokes, they reflect one's social critique, a coping mechanism, an attempt to belong, an assertion, or acceptance of one's identity that is marginalized by hegemonic structures. One example is: "Remember 'ang tunay na lalake walang abs.' (Remember 'a real man has no abs')".

A coping strategy coined, 'cool pose' (Majors \& Billson, 1993) or toughguy performance, actuated by black men to cope with not having the means to fulfil traditional gender roles was observed by Majors and Billson (1993). In contrast, instead of highlighting or exaggerating other hegemonic masculine attributes (such as 'tough-guy'), these tweets mock the tough-guy image and in doing so put forward an alternative of what a 'real man' should be: "ang tunay na lalake umiiyak!! (A real man cries.); ang tunay na lalake takot sa ipis (A real man is afraid of cockroaches)".

McQueen (2017), in a study on the emotionality of white, heterosexual men, showed that while expressing emotions is not usually attributed to men, this is changing given the increasing influence of therapeutic discourse. The tweets above demonstrate or advocate that men can or should be in touch with their emotions. This is tantamount to saying that 'It's okay, boys do cry!' and 'Don't be ashamed to cry or admit you are afraid of cockroaches'.

Resistance through direct critique. Some tweets are more direct in their critique of hegemonic masculinity. They directly question the 'real man' concept and advocate for masculinity which does not depend on the number of women one has had sex with and respects all genders. These tweets seem to police those who hold on to orthodox masculinity (e.g., media) or perpetuate hegemonic masculinity, or its obsolete forms. 
Padamihan ng nadadale? yan na ba ang sukatan ng tunay na lalake (?) (Is the number of women one has had sex with really the measure of being a real man?).

Ang tunay na lalake may respeto sa babae pero mas better kung ang tunay na lalake may respeto sa lahat $n g$ antas $n g$ kasarian at sekswalidad. (A real man respects women but it is better if a real man respects all levels (sic) of gender and sexuality).

Hoy! Ano'ng katangahan to? Walang research sa gender identity magka-headline lang? Edukado na ang maraming institusyon tungkol sa SOGIE tapos kayo 'tunay' na lalake pa rin ang hanash? Walang time magsaliksik? Nakakaputangina, di ba? (Hey! What stupidity is this? Without doing any research on gender identity, (you do this) just to have a catchy headline? Many institutions are now educated about SOGIE but you still use 'real men'? Don't you have time for research? (expletive), right?).

Admitting and correcting mistakes by saying 'sorry' should also not be seen as a weakness but a trait of a 'real man', as one tweet says: “(...) Ang tunay na lalake marunong umamin at iwawasto ang pagkakamali at ang tunay na nalalake nagsosorry" (A real man knows how to admit and correct his mistakes, and a real man knows how to say sorry).

The sarcasm and call for depth in character distinguish these tweets from romantic tweets. Here, resistance is done by recasting masculinity demanding an updated basis of discourse, elevating catchphrases towards inclusivity and behavioral change. This is similar to efforts to involve men such as campaigns like "Man Up, Stop Violence Against Women" ("Man Up", n.d.) and "Real Men Don't Buy Girls" (Flores, n.d.). However, these tweets have yet to be elevated to a formal campaign platform. It should also be noted that while 'tweets of resistance' exist, they remain the minority. And often, these tweets are followed by comments which assert hegemonic masculinity. 


\section{Final Notes}

The study has two sets of findings. The first set consists of contributions to masculinity studies. The second set is the practical implication to online advocacy. This study showed the diversity of 'real man' constructions in Filipino tweets. Three related themes emerged, i) Romance in Masculinity, ii) Masculine Capital, and iii) Resistance to Hegemonic Masculinity. In Romance in Masculinity, several tweets demand respect for women. However, these tweets are heteronormal in content and may be coming from a patriarchal perspective where men protect and infantilize women due to men's perceived ownership of women.

The extracted tweets provide reinforcement or validation to the concept of masculine capital having the ability to overshadow rites of passage. Specifically, being circumcised may be overshadowed by other 'nonmasculine' performances dislodging someone from a 'real man' status to a marginalized form of masculinity.

In Resistance to hegemonic masculinity, we see hope. These are tweets that advocate for gender equality and correct those who perpetuate current hegemonic masculinity. This study also captured tweets that show how a culture transforms, recycles, or adapts the global masculinities discourse. Specifically, a possible Filipino version of the 'cool pose' was seen. It is interesting how the tweets performed the 'cool pose' with a twist - making fun of hegemonic masculinity by asserting non-hegemonic masculine attributes (such as the absence of abs and fear of cockroaches), instead of doing the tough guy performance.

Practical applications to gender equality can be translated from these findings. First, the role of online platforms in gender education is evident. The curated online messages can give some sort of baseline of current gender knowledge, including both stereotypes and aspirations. Second, tweets have to be short. This provides an opportunity to curate messages that stick because they are witty or possess strong emotions many people can relate to.

Whether this resistance will be translated to significant social transformations remains to be seen. We can see from the tweets that, as in the global discourse, Filipino tweets have diverse definitions of 'real man', reinforcing, opposing, and competing with hegemonic masculinity. 


\section{Notes}

${ }^{1}$ (https://t.co/mx18RVmWSq)

\section{Acknowledgments}

Special thanks to Asst. Prof. Ernesto Vasquez del Aguila, Ph.D. (University College Dublin) for introducing me to masculinities studies and for mentoring me in this study; for Prof. Emeritus Amaryllis Torres, Ph.D., Prof. Sylvia Claudio M.D., Ph.D., Assoc. Prof. Nathalie Africa-Verceles, DSD, and Asst. Prof. Rowena Laguilles-Timog, DSD (all from the University of the Philippines) for comments necessary for technical editing and thought-provoking comments, suggestions, and questions that made the completion of this paper possible.

\section{References}

Aguiling-Dalisay, G., Van-Haughten, L.N. and Sto. Domingo, M. (1995). "Ang pagkalalaki ayon sa mga lalaki: pag-aaral sa tatlong grupong kultural sa Pilipinas". Philippine Social Science Review 52:143-166. https://journals.upd.edu.ph/index.php/pssr/article/view/1718

Ancheta, M.R.G. (2011). Halakhak: Defining the national in the humor of Philippine popular culture. Thammasat Review, 14(1), 35-60. http://tujournals.tu.ac.th/thammasatreview/detailart.aspx?ArticleID=1 02

Angeles, L. (2001). The Filipino male as ‘macho-machunurin': Bringing men and masculinities in gender and development studies. Kasarinlan Journal of Third World Studies 16(1):9-30.

https://www.journals.upd.edu.ph/index.php/kasarinlan/article/view/10 73

Allen, L. (2004). 'Getting off' and 'going out': young people's conceptions of (hetero)sexual relationships. Health and Sexuality, 6(6), 463-481. doi: 10.1037/0278-6133.24.2.225

Allen, L. (2007). "Sensitive and real macho all the same time". Young heterosexual men and romance. Men and Masculinities, 10(2), 137152. https://doi.org/10.1177/1097184X05284221

Aresta, M., Pedro, L., Santos, C., \& Moreira, A. (2015). Portraying the self in online contexts: context-driven and user-driven online identity 
profiles. Contemporary Social Science, 10(1), 70-85.

https://doi.org/10.1080/21582041.2014.980840

Bourgois, P. (1995). In Search of Respect: Selling Crack in El Barrio.

New York: Cambridge University Press.

https://doi.org/10.1017/CBO9780511808562

boyd, D. (2008). Why youth <3 social network sites: The role of networked publics in teenage social life. In D. Buckingham (Ed.), Youth, identity, and digital media (pp. 119-142). The MIT Press. https://www.danah.org/papers/WhyYouthHeart.pdf

Connell, R. \& Messerschmidt, J. (2005). "Hegemonic masculinity: rethinking the concept." Gender \& Society 19(6):829-859. https://doi.org/10.1177/0891243205278639

Duncombe, J., \& Marsden, D. (1993). Love and intimacy: the gender division of emotion and 'emotion work': a neglected aspect of sociological discussion of heterosexual relationships. Sociology, 27(2), 221-241. https://www.jstor.org/stable/42855173

Elliot, K. (2016). Caring masculinities: theorizing an emerging concept. Men and Masculinities, 19(3), 240-259. https://doi.org/10.1177/1097184X15576203

Fajardo, K. 2013. Transportation. Translating Filipino and Filipino American tomboy masculinities through global migration and seafaring. In S. Stryker \& A. Aizura (Eds.), The Transgender Studies Reader 2 (pp.527-540). New York: Routledge. https://doi.org/10.1215/10642684-2007-039

Flores, A. (n.d.). Real men don't buy girls. Let's talk: men in the fight. Dressember. https://www.dressember.org/blog/meninthefight

Ging, D. (2017). Alphas, betas, and incels: theorizing the masculinities of the manosphere. Men and Masculinities, 1-20. https://doi.org/10.1177/1097184X17706401

Hanlon, N. (2012). Masculinities, Care and Equality: Identity and Nurture in Men's Lives. Palgrave Macmillan. https://doi.org/10.1057/9781137264879

Hongladarom, S. (2011). Personal identity and the self in the online and offline world. Minds and Machines, 21, 533-548. https://doi.org/10.1007/s11023-011-9255-x

Humphreys, S. \& Vered, K. (2014). Reflecting on gender and digital networked media. Television and new Media, 15(1), 3-13. https://doi.org/10.1177/1527476413502682 
Kearney, M. (no date). Intro to rtweet: Collecting twitter data. https://cran.r-project.org/web/packages/rtweet/vignettes/intro.html

Kimmel, M. (2001). Global masculinities: restoration and resistance. In B. Pease and K. Pringle (Eds.), Man's world? Changing men's practices in a globalized world (Pp.21-37). Zed Books. https://docplayer.net/41888884-Global-masculinities-restoration-andresistance.html

Light, B. (2013). Networked masculinities and social networking sites: a call for the analysis of men and contemporary digital. Masculinities and Social Change, 2 (3), 245-265.

https://doi.org/10.4471/MCS.2013.34

Margold, J. (1995). Narratives of masculinity and transnational migration: Filipino workers in the Middle East. In A. Ong and M. C. Peletz (Eds.), Bewitching women, pious men: gender and body politics in Southeast Asia (pp.76-123). Washington: Berg Publishers. https://doi.org/10.1525/9780520915343-012

Majors, R., \& Billson, J. M. (1993). Cool pose: The dilemmas of black manhood in America. New York, NY, US: Touchstone Books/Simon \& Schuster. https://psycnet.apa.org/record/1995-97721-000

Man Up to Stop Violence Against Women: Burundi. (n.d.). Young African Leaders Initiative. https://yali.state.gov/man-up-to-stopviolence-against-women-burundi/

Manalansan IV, M. (2004). The border between bakla and gay. In Global Divas. Filipino Gay Men in the Diaspora. Durham: Duke University Press. https://doi.org/10.2307/j.ctv12101tn

McQueen, F. (2017). Male emotionality: 'boys don't cry' versus it's good to talk'. NORMA: International Journal For Masculinity Studies, 12(3-4), 205-219. Retrieved from:

https://doi.org/10.1080/18902138.2017.1336877

Nadal, K. L., \& Corpus, M. J. H. (2013). "Tomboys" and "baklas":

Experiences of lesbian and gay Filipino Americans. Asian American Journal of Psychology, 4(3), 166175. https://doi.org/10.1037/a0030168

Nguyen, N-M. (2016). "I tweet like a white person tbh! \#whitewashed”: Examining the language of internalized racism and the policing of ethnic identity on Twitter. Social Semiotics, 26(5), 505523. https://doi.org/10.1080/10350330.2015.1126046 
PettyJohn, M. E., Muzzey, F. K., Maas, M. K., \& McCauley, H. L. (2019). \#HowIWillChange: Engaging men and boys in the \#MeToo movement. Psychology of Men \& Masculinities, 20(4), 612622. https://doi.org/10.1037/men0000186

Pascoe, C. (2007). Dude you're a fag. Adolescent homophobia. In dude you're a fag. Masculinity and sexuality in high school. (Pp.52-83) Berkeley: University of California Press. https://doi.org/10.1525/9780520950696-005

Rubio, R. \& Green, R-J. (2011). Filipino men's roles and their correlates. Development of the Filipino adherence to masculinity expectations scale. Culture, Society \& Masculinities, 3(2), 77-102. https://doi.org/10.3149/csm.0302.77

Schreier, M. (2014). Qualitative content analysis. In U. Flick (Ed.), The SAGE handbook of qualitative data analysis (pp. 170-183). SAGE Publications, Inc. https:// doi.org/10.4135/9781446282243.n12

Siibak, A. (2010). Constructing masculinity on a social networking site. The case study of visual self-representations of young men on the profile images of SNS Rate. Young. Nordic Journal of Youth Research, 18(4), 403-425. https://doi.org/10.1177/110330881001800403

Talbot, K., \& Quayle, M. (2010). The perils of being a nice guy: contextual variation in five young women's constructions of acceptable hegemonic and alternative masculinities. Men and Masculinities, 13(2), 255-278.

https://doi.org/10.1177/1097184X09350408

Terras, M., Ramsay, J., \& Boyle, E. (2015). Digital media production and identity: Insights from a psychological perspective. E-Learning and Digital Media, 12(2), 128-146.

https://doi.org/10.1177/2042753014568179

twitter.developer.com. (no date). "Standard search API". https://developer.twitter.com/en/docs/tweets/search/api-reference/getsearch-tweets.html

Vasquez del Aguila, E. (2014). The early years: becoming a man and masculine capital. In Being a man in a transnational world: The masculinity and sexuality of migration (pp.65-88) New York: Routledge. https://doi.org/10.4324/9781315886565

Zhao, S., Grasmuck, S., \& Martin, J. (2008). Identity construction on Facebook: Digital empowerment in anchored 
relationships. Computers in Human Behavior, 24(5), 18161836. https://doi.org/10.1016/j.chb.2008.02.012

John Erwin Bañez is an assistant professor at the Department of Community Development at the College of Social Work and Community Development, University of Philippines.

Contact Address: Direct correspondence to John Erwin Bañez, Department of Community Development at the College of Social Work and Community Development, University of Philippines Diliman, Quezon City, Philippines, email: jsbanez@up.edu.ph 